Article

\title{
Participatory Plant Breeding and the Evolution of Landraces: A Case Study in the Organic Farms of the Collserola Natural Park
}

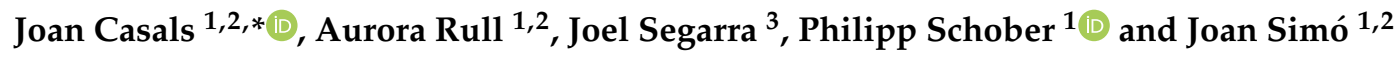 \\ 1 Miquel Agustí Foundation, Campus del Baix Llobregat, Carrer Esteve Terrades 8, Edifici D4, \\ 08860 Castelldefels, Spain \\ 2 Department of Agri-Food Engineering and Biotechnology, BarcelonaTech, Campus del Baix Llobregat, \\ Polytechnic University of Catalonia (UPC), Carrer Esteve Terrades 8, Edifici D4, 08860 Castelldefels, Spain \\ 3 Integrative Crop Ecophysiology Group, Plant Physiology Section, Faculty of Biology, \\ University of Barcelona, 08028 Barcelona, Spain \\ * Correspondence: joan.casals-missio@upc.edu; Tel.: +34-93-552-12-28
}

Received: 29 July 2019; Accepted: 26 August 2019; Published: 27 August 2019

\begin{abstract}
Although consumers appreciate the genetic diversity among tomato landraces, traditional varieties have been displaced from commercial agriculture. Their cultivation through organic farming in natural parks can contribute to their resurgence. With this aim, we developed a participatory plant breeding (PPB) program in Collserola Natural Park (Barcelona, Spain) to promote the conservation of the Mando landrace and to obtain new varieties adapted to local organic farms. Taking advantage of the natural genetic variation from the variety's high cross-pollination rate, farmers developed five experimental inbreeds that were tested in a multi-locality trial in 2018. As a result of the PPB program, cultivation of the original landrace increased from 80 plants in 2011 to more than 2000 plants in 2018, which protected the variety from genetic erosion. Locality was the factor that contributed mostly to agronomic traits (e.g., yield ( $66 \%$ of the phenotypic variance)), while the genotype contributed more to the quality traits (except for soluble solids (37\%) and dry matter (38\%)). Farmer evaluations were highly correlated with the phenotypic traits recorded by researchers (Pearson coefficient ranging from 0.63-0.83), and led to the same final varietal selection. The superior inbred selected (3.9) is now being cultivated in the area of study. This paper discusses the efficiency of PPB in guiding the evolution of landraces.
\end{abstract}

Keywords: tomato; Solanum lycopersicum L.; crop genetic resources; genetic erosion; farmer evaluation; yield stability; sensory analysis

\section{Introduction}

Recent years have seen an increase in organic farmers' interest in participatory plant breeding (PPB), where farmers and scientists work together to share knowledge to increase the efficiency of the process [1]. PPB was initially developed for low-input agro-systems in developing countries to breed varieties adapted to these environments and to increase the rate of adoption of cultivars by small farmers [2]. Currently, this approach is being used to develop new varieties adapted to organic farms [3], which need specific ideotypes [4]. Unlike conventional plant breeding focused on selecting genotypes with 'broad adaptability,' PPB can develop varieties specifically adapted to local environments. This 'specific adaptability' confers important advantages for organic farming. Performing the selection cycles in the agro-systems where the varieties will be cultivated makes it possible to identify advantageous genotype-by-environment $(\mathrm{G} \times \mathrm{E})$ interactions that would be discarded in conventional breeding [5]. 
Organic farmers appreciate local landraces, considering them a mark of quality that helps to differentiate their produce in the marketplace. Nevertheless, more than $95 \%$ of organic agriculture is based on modern varieties developed through conventional plant breeding programs [4]. Although landraces' resilience and yield stability [6] are good for the heterogenic agronomic conditions among organic farms $[7,8]$, landraces usually lack some important agronomic traits that are necessary to make them profitable in modern agriculture. In this context, PPB can play an important role in the development of second-generation landraces that retain their singular characteristics while incorporating important agronomic traits [9]. Respect for genetic integrity, preservation of genetic diversity, and empowerment of farmers and appreciation of their knowledge have made PPB (and the methodological variant participatory variety selection (PVS) [10]) better perceived than conventional breeding in the organic sector.

Most case studies on PPB have focused on staple crops in developing countries. Few have focused on vegetables in developed countries. Of the 172 publications on PPB reviewed by Ceccarelli and Grando [11], most were focused on staple crops, e.g., rice (Oryza sativa L.), maize (Zea mays L.), bean (Phaseolus vulgaris L.), sorghum (Sorghum sp.), barley (Hordeum vulgare L.), or potato (Solanum tuberosum L.), and few publications were focused on vegetables. Very few reports of PPB programs for tomato (Solanum lycopersicum L.) have been published [12-14]. The wealth of tomato landraces originating in Europe, a secondary center of diversification of the species $[15,16]$, can be an important source of variation in developing new quality cultivars adapted to organic agro-systems.

In 2011, we started a PPB program in the organic agro-systems of Collserola Natural Park (Barcelona, Spain) to protect the nearly extinct Mandó de Collserola (Mando) landrace from genetic erosion and promote its evolution directed by farmer's needs and knowledge. In this scenario, we report the results of a seven-year PPB program with the endangered tomato landrace Mando and analyzed the evolution of the landrace under the effects of the PPB.

\section{Materials and Methods}

\subsection{Plant Materials}

The plant breeding program started in 2011 with an initial population of Mando landrace comprising 80 plants cultivated on a farm (Can Mandó) located in Collserola Natural Park (Figure 1). Two subpopulations (SP1 and SP2) with clearly different phenotypic plant and fruit traits were identified. Variation within each subpopulation was low. Seeds from self-pollinated flowers were obtained from 10 plants in each subpopulation. From 2012 to 2017, successive progenies were studied at an experimental station in the northern part of the park. Among progenies from SP1, the phenotype remained stable through the years and no significant differences were observed between individual plants. Farmers considered SP1 to be the original landrace (i.e., the material was considered a pure line of the Mando landrace). The Mando landrace produces externally red, slightly flattened beef-type fruits (mean weight, $400,500 \mathrm{~g})$ [17].

SP2 segregated in the first year of the study (2012) and during the following years (2013-2017). No information on the phylogeny of the population was available. However, Mando flowers have an exserted stigma, and this trait promotes cross-pollination in tomato [18]. Thus, cross-pollination can explain the occurrence of SP2 in the fields where the landrace was cultivated. All SP2 plants detected in the field the first year were similar, so we ruled out mutation and Mando inbred $\times$ commercial hybrid as possible origins of the subpopulation. We assumed that SP2 plants identified in 2011 were a spontaneous hybrid between Mando and an unknown line and that self-pollinating the SP2 plants each year would advance toward the homozygous state of the genotypes (the S7 generation was achieved in 2018).

Each year, 100 plants of the progeny were cultivated in the experimental station, and, when the fruits on the third truss ripened, farmers $(n=15)$ were invited to select the best 10 plants. From the first year of segregation, yellow-to-orange SP2 fruits appeared, and farmers prized these plants, arguing that new colors of fruit would help differentiate the new breeding materials from the original landrace. 
In 2017, the final 10 genotypes were cultivated and farmers selected the best 5 lines. Four of these had yellow fruits (coded as 4.3, 4.8, 3.4, and 3.9) and one of these had red fruits (5.5) (Figure 2). For the final participatory variety selection (PVS) trial in 2018, we used seeds obtained from self-pollinated flowers of these 5 lines, the Mando landrace pure line, and the cultivar Rosa Candido (a pure line of the Rosa de Barbastro landrace widely grown by the farmers of the area that has fruit morphology very similar to Mando).
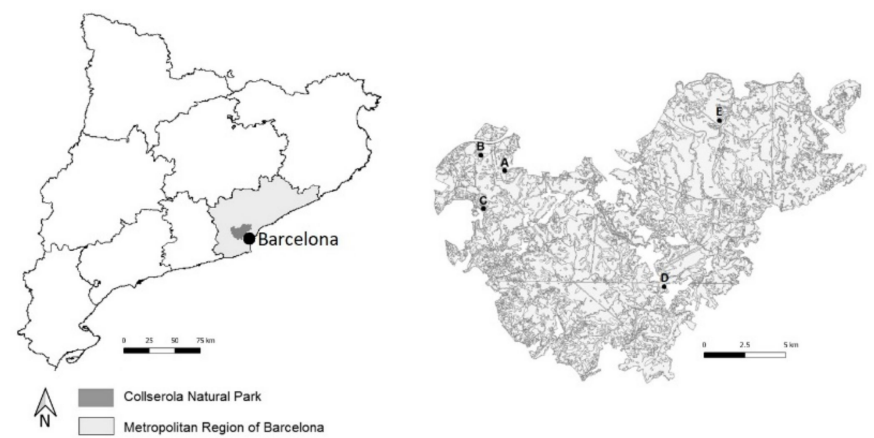

Figure 1. Location of the fields where the PVS trial was performed in 2018 (A, Ortiga, B, Can Domènech, and C, Can Puig), the farm where the study started in 2011 (D, Can Mando), and the research station where the breeding program was developed from 2012 to 2017 (E).

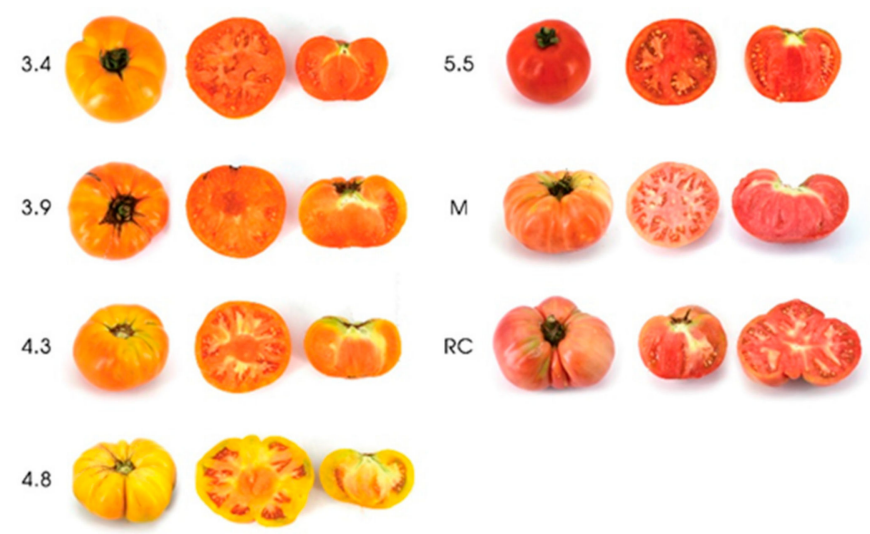

Figure 2. Fruits from the breeding lines (3.4, 3.9, 4.3, 4.8, 5.5), the original Mando landrace (M), and the cultivar Rosa Candido (RC) used in the participatory variety selection (PVS) trial conducted in 2018.

\subsection{Experimental Design}

In 2018, farmers collaborating in the PPB program cultivated plant materials in the open air at 3 localities: Can Domènech ( $\left.41^{\circ} 27^{\prime} 28.50^{\prime \prime} \mathrm{N}, 2^{\circ} 01^{\prime} 13.93^{\prime \prime} \mathrm{E}\right)$, Can Puig (412 $\left.27^{\prime} 03.48^{\prime \prime} \mathrm{N} 2^{\circ} 01^{\prime} .19 .61 \mathrm{E}\right)$, and Ortiga $\left(41^{\circ} 27^{\prime} 04.81^{\prime \prime} \mathrm{N}, 2^{\circ} 01^{\prime} 56.93^{\prime \prime} \mathrm{E}\right)$. Seeds of the experimental genotypes were sown on 15 February 2018 in a professional organic plant nursery (Planters Casas, Palafolls) and transplanted on 14 April, 2018. Cultivation lasted until 12 September, 2018 (total: 151 days from transplant to the last harvest). Minimum, maximum, and average temperatures throughout the growing period were $9.1{ }^{\circ} \mathrm{C}, 30.4{ }^{\circ} \mathrm{C}$, and $20.9^{\circ} \mathrm{C}$, respectively, with a total reference evapotranspiration of $621.9 \mathrm{~mm}$. On each farm, we used an experimental design consisting of 2 blocks and 10 plants per plot (i.e., 20 plants/genotype * 7 genotypes $=140$ plants/locality). Plants were conducted vertically on a single stem, using canes (Arundo donax L.) to support the plant and removing the lateral sucks every 10 to 15 days, depending on plant vigor and crop cycle. Farmers used their own approaches to fertilization and pest and disease control, but all followed certified organic farming procedures [19]. In each locality, soil analysis was performed in a bulk sample consisting of 6 subsamples collected randomly in each field the same day of the transplant. $\mathrm{pH}$ (potentiometric method), electrical conductivity, organic matter (weight loss on ignition method), nitrogen $\left(\mathrm{NO}_{3}{ }^{-}\right)$(colorimetric method), phosphorus $(\mathrm{P})$ (spectrophotometry 
UV-Vis), potassium (K), calcium (Ca), and magnesium $(\mathrm{Mg})$ (spectrometry ICP-OES), and textural class (gravimetric method) were determined. Results show that farms have similar soil texture (loamy), soil $\mathrm{pH}(8.3-8.4)$, and high soil calcium $(>6.500 \mathrm{mg} / \mathrm{kg})$, but differ greatly in soil characteristics related to fertility. For instance, organic matter content ranges from $2.1 \%$ to $4.3 \%$ and nitrates range from 13.9 to $40.0 \mathrm{mg} / \mathrm{kg}$ (Table 1 ).

Table 1. Soil characteristics of the three experimental fields.

\begin{tabular}{cccc}
\hline Locality & Can Domènech & Can Puig & Ortiga \\
\hline $\mathrm{pH}$ & 8.32 & 8.41 & 8.34 \\
Electrical conductivity $(\mathrm{ds} / \mathrm{m})$ & 0.274 & 0.351 & 0.236 \\
Organic matter $(\%)$ & 3.49 & 4.29 & 2.1 \\
Nitrogen $\left(\mathrm{NO}_{3}^{-}\right)(\mathrm{mg} / \mathrm{kg})$ & 13.9 & 40.0 & 13.9 \\
Phosphorus $(\mathrm{P})(\mathrm{mg} / \mathrm{kg})$ & 85 & 95 & 62 \\
Potassium $(\mathrm{K})(\mathrm{mg} / \mathrm{kg})$ & 609 & 942 & 203 \\
Calcium $(\mathrm{Ca})(\mathrm{mg} / \mathrm{kg})$ & 6883 & 7267 & 7172 \\
Magnesium $(\mathrm{Mg})(\mathrm{mg} / \mathrm{kg})$ & 383 & 430 & 277 \\
Textural class & Loam & Loam & 42.2 \\
Sand $(0.05<\mathrm{D}<2 \mathrm{~mm})(\%)$ & 38.3 & 38.8 & 20.6 \\
Silt coarse $(0.02<\mathrm{D}<0.05 \mathrm{~mm})(\%)$ & 22.9 & 20.4 & 16.6 \\
Silt fine and medium $(0.002<\mathrm{D}<0.02 \mathrm{~mm})(\%)$ & 15.9 & 18.3 & 20.6 \\
Clay $(\mathrm{D}<0.002 \mathrm{~mm})(\%)$ & 22.9 & 22.6 & \\
\hline
\end{tabular}

\subsection{Phenotyping by Breeders}

During the crop cycle, researchers recorded the following agronomic traits: yield (kg/plant), fruit weight $(\mathrm{g})$, total number of fruits per plant, and incidence of physiological disorders (fruit cracking and blossom-end-rot, in percentage of fruits affected per plant). Ten red-ripe-stage (RR) fruits were harvested from the second to the fourth trusses for physicochemical analyses. Color was evaluated in the equatorial section of each fruit with a colorimeter (Konica Minolta CR-410, Minolta, Osaka, Japan) and expressed as $\mathrm{L}^{*}, \mathrm{a}^{*}$, and $\mathrm{b}^{*}$ coordinates from the CIELAB color space. Five individual fruits were used to determine soluble solids content (SSC), which were measured with a hand refractometer (Erma, Tokyo, Japan) and expressed in ${ }^{\circ}$ Brix. Firmness was measured with a durometer (Agrosta Durofel, Compainville, France) and expressed as a percentage. Lastly, 10 fruits from each genotype and locality were divided in 3 bulks, blended, and analyzed for titratable acidity (TA, titration with $\mathrm{NaOH} 0.1 \mathrm{M}$ up to $\mathrm{pH}=8.1$, expressed as g citric acid/100 $\mathrm{g}$ fresh weight), dry matter (measured by drying samples in an air oven to constant weight $\left(65^{\circ} \mathrm{C}, 72 \mathrm{~h}\right.$ ), as a percentage), and $\mathrm{pH}$ (measured with a $\mathrm{pH}$-meter CRISON micropH 2001).

\subsection{Phenotyping by Farmers}

Prior to transplanting the crop, farmers $(n=15)$ were emailed a questionnaire designed with and hosted online with Google Forms. Farmers were asked to score different traits (adapted from Hoagland et al. [12]) on the extent to which they considered them important for inclusion in a breeding program, using an 11-point scale $(0=$ not important at all, $10=$ very important).

Taking into account the results of this preliminary survey (Table 2), farmers decided to study flavor-related traits by means of sensory analysis (Section 2.5), and to characterize the agronomic behavior (including resistance to physiological disorders, and yield) and fruit morphological traits (including fruit color and shape) in the field. With this aim, on 17 July, prior to the first harvest, 10 farmers participated in a field seminar, including a training session conducted by researchers, where the group discussed and agreed on the traits that would be studied: potential yield (i.e., expected $\mathrm{kg}$ fruits/plant), fruit appearance (i.e., whether the fruits would be attractive for consumers), and fruit marketability (i.e., number of marketable fruits/plants). Moreover, a consensus scale was established $(0=$ not interesting, $10=$ very interesting $)$ to evaluate plants on these traits, and the group discussed 
and scored together 10 plants from a single locality. Once farmers had been trained in the phenotyping method, each farmer individually scored the plants from the 3 trials (the group decided to phenotype only the first block from each locality, i.e., 10 plants per genotype and locality $=70$ plants per locality scored by each farmer).

Table 2. Mean scores for the importance of traits to be included in the tomato breeding program in the survey completed by farmers $(n=15)$. Scale ranging from $0=$ not important at all to $10=$ very important. Different letters indicate significant differences (Student-Newman-Keuls test, at $p<0.05$ ).

\begin{tabular}{ccc}
\hline Trait & Mean Score & \\
Flavor & 9.6 & $\mathrm{a}$ \\
Fruit color and shape & 9 & $\mathrm{ab}$ \\
Resistance to physiological disorders & 8.7 & $\mathrm{bc}$ \\
Yield & 8.6 & $\mathrm{bc}$ \\
Storability & 8.4 & $\mathrm{bc}$ \\
Disease resistance & 8.4 & $\mathrm{bc}$ \\
Nutritional quality & 7.9 & $\mathrm{~cd}$ \\
Water use efficiency & 7.1 & $\mathrm{de}$ \\
Nutrient use efficiency & 6.6 & $\mathrm{de}$ \\
Plant architecture (growth habit) & 6.4 & $\mathrm{de}$ \\
Weed competitiveness & 5.6 & $\mathrm{e}$ \\
\hline
\end{tabular}

\subsection{Phenotyping by Consumers}

On 1 August, in Montcada i Reixac, we surveyed 59 consumers (gender: female 36\%, male $64 \%$, age: $18-30$ years 32\%, 31-45 years $24 \%, 45-65$ years 37\%, > 65 years $7 \%$, frequency of tomato consumption: every day $46 \%, 3-4$ times per week 39\%, 1-2 times per week 14\%, 1-3 times per month $2 \%$. Frequency of consumption of organic vegetables: always $14 \%$, sometimes $71 \%$, never $15 \%$ ). Fruits from the Can Puig locality harvested at the RR stage were presented to consumers, who scored the traits' fruit appearance (on a batch of two whole and two equatorially sliced fruits) and, subsequently, the traits' fruit texture and fruit flavor (on longitudinal slices of the fruits). Consumers were asked to score their preference on a scale ranging from 0 (dislike) to 10 (like very much), following previously developed protocols for hedonic surveys [20,21].

\subsection{Statistical Analyses}

Variables were analyzed individually by means of analysis of variance (ANOVA), using a full factorial model considering all the factors in the design (except for agronomic traits, for which the block effect was considered a factor nested within a locality factor). For significant factors, the Student-Newman-Keuls test was used for means separation $(p<0.05)$. To study the relative contribution of each factor to the phenotypic variation, the total sum of squares was partitioned into the sums of squares of genotype, locality, block (locality), genotype $x$ locality, and residual effects, as proposed by Figàs et al. [22]. Phenotypic stability for yield was studied with a simple linear regression, as proposed by Eberhart and Russell [23]. Genotypes were considered stable if $b_{1}$ (coefficient of regression) $=1, \mathrm{sd}^{2}$ (deviation from linearity) $=0$, and $r^{2}$ (coefficient of determination) $>0.50$ [24]. A principal component analysis (PCA) was performed using standardized data $(\mu=0, \sigma=1)$ among means for farmers' evaluations in each locality. To identify phenotypic correlations among farmers' scores and between farmers' scores and yields measured by breeders, we calculated the Pearson coefficient. All statistical analyses were performed using SPSS (v.12.0, SPSS Inc., Chicago, IL, USA) software.

\section{Results}

\subsection{Farmers' Ideotype}

The survey found that farmers considered flavor and fruits' external appearance the most important breeding priorities. These traits were ranked significantly higher than agronomic performance (yield, 
disease resistance) and post-harvest storability (Table 2). Issues related to the environmental impact of tomato production (water and nutrient use efficiency) and nutritional quality were considered less important. Weed competitiveness of the plant materials was not considered important, likely because most farms use mulching to control weeds during cultivation.

\subsection{Genotype and Environmental Effects}

The genotype and locality factors were significant for all the traits studied, except for the incidence of blossom-end rot (Table 3). The contribution of the locality factor to the phenotypic variation ranged from $2.0 \%$ to $65.7 \%$ for the agronomic traits and from $2.5 \%$ to $38.4 \%$ for the quality traits. The contribution of the genotype factor to the phenotypic variation ranged from $4.2 \%$ to $47.5 \%$ for the agronomic traits and from $18.0 \%$ to $68.3 \%$ for quality traits. The locality factor was the main contributor to agronomic performance, which accounted for $68.3 \%$ of sums of squares for yield and $37.3 \%$ for number of fruits per plant. The genotypic effect for these traits was low but significant (4.2\% for yield, $15.7 \%$ for the number of fruits per plant). The highest yields were recorded in the Can Puig locality (mean value: $3.8 \mathrm{~kg} / \mathrm{plant}$ ). The yields were significantly lower at Can Domènech $(1.5 \mathrm{~kg} / \mathrm{plant})$ and Ortiga (0.9 kg/plant) (Figure 3). The differences in agronomic performance between localities were in line with the respective fertility levels of the farms (Table 1). Among agronomic traits, the genotypic effect was highest for fruit weight $(47.5 \%)$. For fruit quality traits, the genotype factor contributed much more to phenotypic variation. For instance, the percentage of sums of squares attributable to the genotype was $52.6 \%$ for titratable acidity and $30.0 \%$ for firmness, while locality contributed only $4.3 \%$ for titratable acidity and $13.3 \%$ for firmness. Color was affected primarily by genotype $\left(\mathrm{L}^{*}, 38.5 \%\right.$, $\mathrm{a}^{*}$, $44.6 \%$, and $b^{*}, 68.3 \%$ ) and by the GxE interaction (genotype $x$ locality) ( $\mathrm{L}^{*}, 18.7 \%, \mathrm{a}^{*}, 24.4 \%$, and $\mathrm{b}^{*}$, $9.4 \%)$. Sugar content, measured as SSC, was affected by locality (36.9\%), but also significantly affected by genotype (20.5\%) and the GxE interaction (17.9\%). The SSC values recorded in Can Domènech $\left(5.1^{\circ}\right.$ Brix) and Ortiga (5.0 ${ }^{\circ}$ Brix) were significantly higher than those recorded in Can Puig (4.1 ${ }^{\circ}$ Brix), where the yield was higher (Figure 3). The $G \times E$ interaction was significant for all the traits except firmness. The GxE interaction was not the greatest contributor to the sums of squares for any trait, but seems more important for fruit quality traits (SSC, pH, dry matter) than for agronomic performance.

Table 3. Percentage of the total sums of squares and significance for the factors considered in the ANOVA model for agronomic and fruit quality traits.

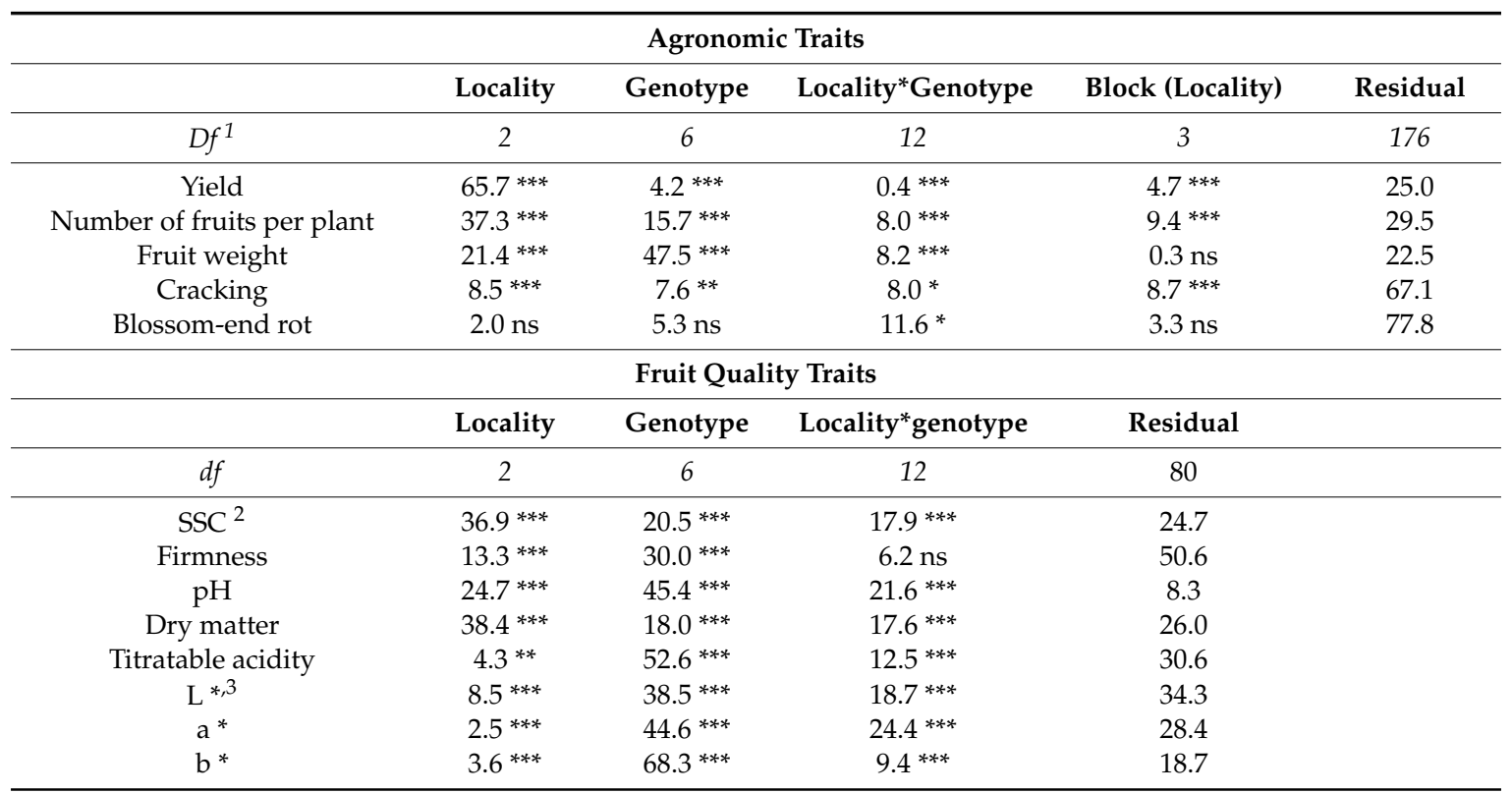

${ }^{1} \mathrm{df}$ : degrees of freedom. ${ }^{2}$ SSC: Soluble solids content. ${ }^{3} \mathrm{~L}^{*}$ (luminosity), $\mathrm{a}^{*}$ (green-to-red), and b* (blue-to-yellow) are coordinates from the CIELAB color space. 

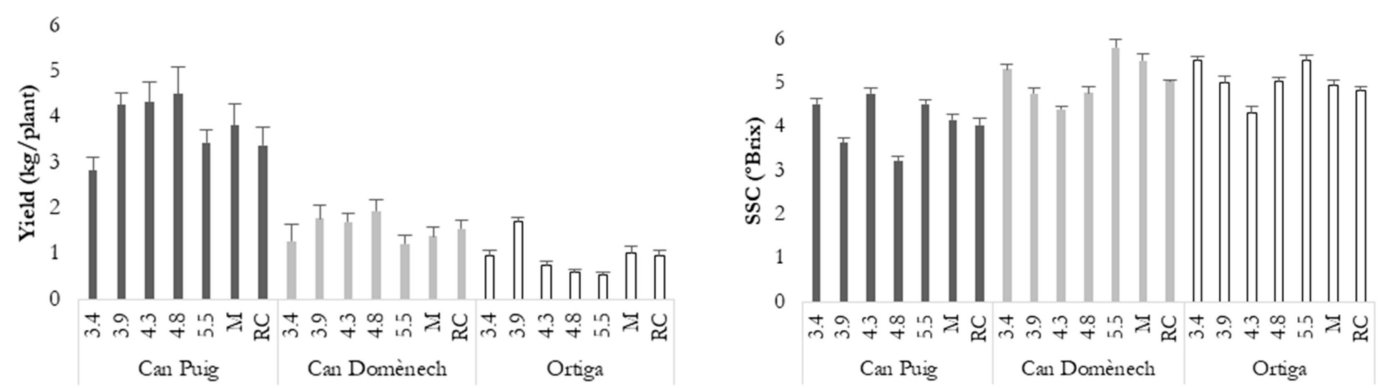

Figure 3. Mean values per genotype and locality for yield and soluble solids content (SSC). Bar errors represent the standard error of the mean. Experimental lines: 3.4, 3.9, 4.3, and 5.5. Controls: M (Mando), RC (Rosa Candido).

\subsection{Farmers' Evaluation and Yield Stability}

Ten farmers participated in the characterization of the materials, with each one scoring 210 plants for the traits' potential yield, fruit appearance, and fruit marketability. The traits evaluated were significantly and positively correlated with one another (potential yield with fruit appearance, $r=0.695$, potential yield with fruit marketability, $r=0.686$, and fruit appearance with fruit marketability, $r=0.675$ ), which signals that plants with good ratings for one trait also had good ratings for the other traits. Moreover, farmers' evaluations and the phenotypic traits recorded by breeders were highly correlated. For instance, the correlations between farmers' scores of the potential yield and the "real" yield (kg/plant) ranged from 0.631 to 0.826 (Pearson coefficient).

In the PCA on farmers' evaluations, the first component (PCA1) accounted for $42 \%$ of the total variation, and the second component (PCA2) accounted for $28 \%$ (Table 4, Figure 4). PCA1 was positively correlated with potential yield in the three localities, and with fruit marketability in Ortiga and Can Domènech. PCA2 was positively correlated with fruit appearance in the three localities. Thus, the genotypes positioned in the upper-right quadrant of the PCA1-PCA2 scatterplot were considered better (Figure 4). According to farmers' evaluations, 3.9 was the best genotype. It obtained significantly higher scores for potential yield and fruit appearance than the other genotypes and it was in the second group of significance for fruit marketability (below genotype 3.4). Mando obtained intermediate overall scores for fruit marketability, but low scores for potential yield and fruit appearance. Thus, according to the farmers' scores, the PPB program resulted in improved pure lines in comparison with the original landrace.

Table 4. Correlation coefficients between farmers' evaluations and the first and second principal components in the Ortiga, Can Puig, and Can Domènech localities.

\begin{tabular}{ccc}
\hline & PCA1 (42\%) & PCA2 (28\%) \\
\hline Potential yield_Ortiga & 0.589 & 0.358 \\
Fruit appearance_Ortiga & 0.226 & 0.943 \\
Fruit marketability_Ortiga & 0.752 & -0.143 \\
Potential yield_CanPuig & 0.648 & -0.398 \\
Fruit appearance_CanPuig & 0.205 & 0.826 \\
Fruit marketability_CanPuig & -0.416 & -0.017 \\
Potential yield_Can Domènech & 0.916 & -0.296 \\
Fruit appearance_Can Domènech & 0.728 & 0.570 \\
Fruit marketability_Can Domènech & 0.876 & -0.432 \\
\hline
\end{tabular}




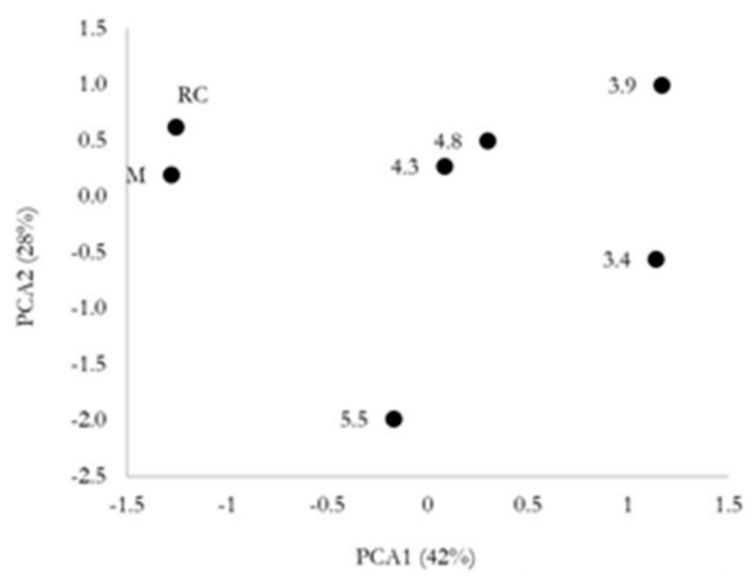

Figure 4. The PCA1-PCA2 scatterplot from the principal component analysis conducted on farmers' evaluations of potential yield, fruit appearance, and fruit marketability.

To determine whether the genotypes selected in the farmers' evaluations were stable, high-yielding genotypes, according to the criteria proposed by Ortiz and Izquierdo [24] (i.e., yield $>$ the grand mean, regression coefficient $b_{1} \leq 1.0$, and coefficient of determination $>0.5$ ), we plotted the regression coefficients against mean yields recorded by breeders for each genotype (Figure 5). This analysis found that genotype 3.9 had a high yield across environments, which confirms the results of the farmers' evaluation. The original Mando landrace was also stable across environments, but the yield was not significantly different from the grand mean.

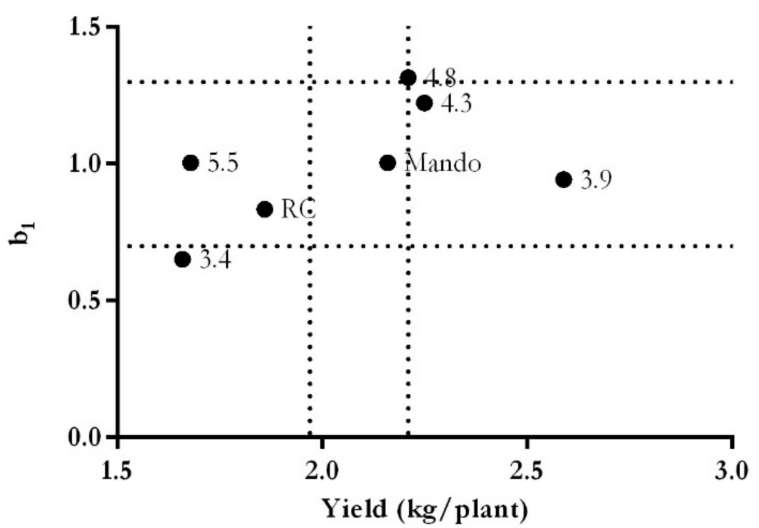

Figure 5. Regression coefficients $\left(b_{1}\right)$ plotted against mean genotype yields. Lines parallel to the $\mathrm{X}$-axis separate values statistically different from 1.0, and lines parallel to the Y-axis separate values significantly higher or lower than the grand mean. Genotypes located in the area where yield is greater than the grand mean and $b_{1} \leq 1.0$ are regarded as stable, high-yielding genotypes.

\subsection{Consumer Preferences}

On average, all the genotypes had good scores for the three traits evaluated by consumers, which range from 6.3 to 8.6 for fruit appearance, 6.9 to 8.0 for texture, and 6.6 to 8.1 for flavor on a scale from 0 (dislike) to 10 (like very much) (Figure 6). It should be noted that fruits used in the sensory analysis experiment were harvested in the locality of Can Puig, which was characterized by high yields but low sugar content (SSC). Moreover, our plant materials included yellow-fruited, pink-fruited, and red-fruited varieties, and fruit color may have influenced consumers' evaluations of flavor and texture [25]. For this reason, Figure 6 groups varieties by color (yellow, pink, and red) to facilitate comparisons. The best genotypes were red-fruited varieties (Mando and the experimental line 5.5). The yellow-fruited varieties and the Rosa Candido control had significantly lower scores for fruit appearance and flavor. Consumers found scant differences between the different yellow-fruited varieties $(3.4,3.9,4.3$, and 4.8). 

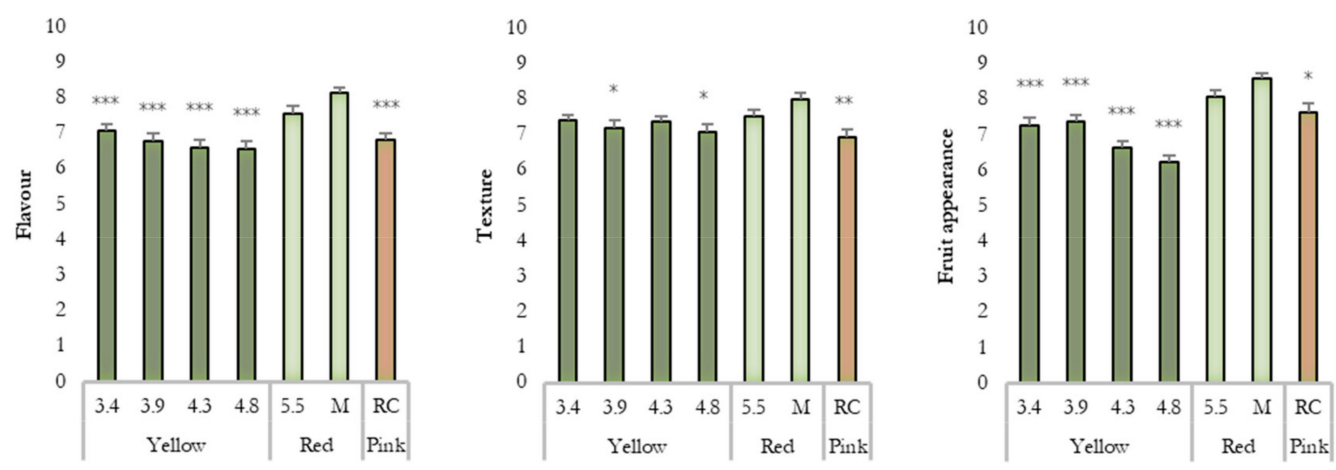

Figure 6. Consumer's $(n=59)$ scores for flavor, texture, and fruit appearance for the breeding lines, the original Mando landrace (M), and the commercial variety Rosa Candido (RC). Bar errors represent the standard error of the mean. Scores significantly different from the original landrace (Mando, M) are marked with asterisks $\left({ }^{*} p<0.05,{ }^{* *} p<0.01,{ }^{* * *} p<0.001\right.$, according to the Student-Newman-Keuls test).

\section{Discussion}

In addition to their role in protecting wild ecosystems, natural parks can play a role in the conservation of crop genetic resources [26]. Natural parks tend to be isolated from intensive agricultural areas, and this separation can help protect fields where landraces are cultivated from the transmission of some pests and diseases as well as of genes in pollen from improved varieties. Tomato landraces are susceptible to the viruses that can affect tomato crops [27], which makes it unviable to cultivate them in intensive horticultural areas. In the eight-year PPB program described in this paper, we observed no viral infections, even though Tomato Mosaic Virus (TMV) and Tomato Spotted Wilt Virus (TSWV) were detected in the surrounding area during this period.

Tomato landraces' singular fruit shapes and sensory quality attributes are highly valued $[15,16]$. Despite the wide genetic diversity in European agrosystems, these varieties are usually cultivated solely in home gardens managed by older farmers [28] and are, thus, threatened with genetic erosion. Participatory approaches can help reintroduce these varieties in horticultural fields, especially in natural parks and under organic farming, where farmers are highly sensitive to issues related to conserving agrobiodiversity. The current project started with a field with 80 plants of the Mando landrace managed by a single farmer. The PPB program has made it possible to protect the landrace, with seeds stored in the seed bank of the Miquel Agustí Foundation/Barcelona School of Agricultural Engineering [29], and to spread its cultivation to the point where more than 2000 plants of the original landrace were cultivated in 2018. Thus, the PPB program has helped improve both the in situ and ex situ conservation of the variety.

Importantly, the PVS trial found that the commercial variety Rosa Candido, which was initially occupying the landrace's market niche, yielded less (Rosa Candido: $1.8 \pm 0.2 \mathrm{~kg} / \mathrm{plant}$, Mandó: $2.2 \pm 0.3 \mathrm{~kg} / \mathrm{plant}$ ) and was rated lower by consumers (Figure 6) when grown in the fields of the original area of the Mando landrace. The replacement of landraces by modern varieties is one of the most important factors contributing to the genetic erosion of landraces [30], but, in this study, it seems that farmers were growing the commercial variety not because it performed better, but rather because it was easier for them to obtain plant materials.

Organic farms tend to have greater agronomic heterogeneity than conventional farms, as fertility and pest and disease control depend largely on ecosystemic services, both at the field and landscape levels, rather than on external inputs [31]. Plant breeding programs for organic farming should consider this agronomic variability [4], and selection criteria should incorporate the genotype but also the G $\times$ E effects that positively affect plant yield and quality traits in the target environments [32]. In this work, we identified great heterogeneity between the three farms, including important differences in soil fertility (nitrogen content ranged from $13.9 \mathrm{mg} / \mathrm{kg}$ to $40.0 \mathrm{mg} / \mathrm{kg}$ and organic matter from $2.1 \%$ to $4.3 \%$ ), which had an impact on yields (from $0.9 \mathrm{~kg} / \mathrm{plant}$ in Ortiga to $3.8 \mathrm{~kg} / \mathrm{plant}$ in Can Puig) and 
quality. Locality was the factor that contributed most to the agronomic behavior of the varieties (yield $(65.7 \%)$ and number of fruits per plant $(37.3 \%))$, and also on some quality traits (SSC (36.9\%) and dry matter $(38.4 \%))$, which tend to be correlated with the agronomic behavior $[33,34]$. Other studies on tomato landraces have also found that the locality factor is very important for agronomic and quality traits $[17,22,35]$, which shows landraces' sensitivity to the growing environment. On the other hand, some important quality traits (fruit weight, color, firmness, and the acid fraction of the fruit) were less affected by the environment, and were highly determined by the genotype. Other authors have shown that these traits have higher heritability [36,37].

The participation of farmers in plant breeding programs facilitates the inclusion of target traits they consider important in the selection criteria, and it also makes it possible to take advantage of their technical skills in evaluating plant materials [38]. In our study, farmers' evaluations of potential yields correlated strongly with the "real" yield measured by breeders, with a Pearson coefficient ranging from 0.631 to 0.826 among participants. Moreover, analyzing farmer's evaluations of potential yield, fruit appearance, and fruit marketability (Figure 4, Table 4) resulted in the same final selection as the classical approach of selecting the stable, high-yielding genotypes based on plant yield data (Figure 5). Thus, farmers are highly skilled at quantitatively describing the agronomic performance of segregating tomato populations in the field, which has been reported in studies with other species [38-40]. Therefore, researchers in PPB programs should focus on plant genetics (designing and guiding the evolution of the segregating populations), the implementation of robust and affordable experimental designs, data analysis, and phenotyping of complex traits that requires advanced technologies. In other words, for agronomic traits, researchers' participation should focus more on organization than on data collection.

In recent decades, tomato flavor has become more important for consumers [41] and for farmers [12]. In our study, flavor and fruit appearance ranked first amongst farmers' priorities for breeding new, organic tomato varieties. However, it can be difficult to phenotype segregating populations for complex traits such as sensory attributes for which indirect determination with chemical or molecular markers is still ineffective [42,43]. In this study, we did not assess internal sensory attributes during the PPB program, and farmers' initial strategy of selecting yellow-fruited variants to diversify their offer seems to have had a profoundly negative impact on consumers' acceptance of the new varieties. Yellow tomato fruits have lower concentrations of lycopene and carotenoid-derived volatiles, which are important in the perception of tomato flavor [44]. Thus, selecting yellow genotypes profoundly altered the sensory profile of the new varieties, which resulted in lower consumer ratings of the new breeding lines. For the three traits rated (fruit appearance, flavor, and texture), consumers showed a significantly higher preference for red-fruited varieties (Mando and experimental line 5.5) than for yellow (experimental lines 3.4, 3.9, 4.3, and 4.8) or pink (Rosa Candido) genotypes. Thus, the farmers' initial criteria were not aligned with consumers' preferences, even though consumers' overall ratings for the new varieties was good (values higher than 6 on a 0-10 scale). These results show the importance of having consumers participate in the early stages of the PPB program. Moreover, collaboration between farmers and consumers in PPB programs promises to reinforce relationships between these groups and to promote short food supply chains.

\section{Conclusions}

Participatory plant breeding can be an efficient approach for driving the evolution of landraces. Instead of regarding landraces as fixed and finished genetic populations, their evolution toward optimal adaptation to specific agroclimatic areas can help reinforce their cultivation. Integrating farmers' knowledge and consumer preferences from the early stages of plant breeding programs can help develop a new generation of landraces that will fit agronomic and commercial standards more efficiently. This process is compatible with the conservation of plant genetic resources. In this study, taking advantage of the natural variation originating in the field to create new varieties did not subvert the goal of protecting the original landrace from genetic erosion. The cultivation was expanded from 80 plants at the beginning of the program (2011) to more than 2000 plants at the end of the program (2018). Farmers' 
innovative bet on yellow-fruited inbreeds failed to impress consumers, but setbacks in the evolution of cultivated plants are common.

Author Contributions: Conceptualization, J.C. Methodology, J.C. Investigation, J.C., A.R., J.S. (Joel Segarra), and P.S. Data curation, J.C. and J.S. (Joel Segarra). Writing—original draft preparation, J.C. Writing—review and editing, J.C. and J.S. (Joan Simó). Supervision, J.S. (Joan Simó). Funding acquisition, J.C.

Funding: The Consorci del Parc Natural de la Serra de Collserola funded this research.

Acknowledgments: The authors thank the farmers Pol Domènech (Can Domènech), Kevin Fisher, Sergi Turch (Ortiga), and Moha (Can Puig) for their contribution to this work by conducting the field trials. We are also grateful to Joan Vilamu for his technical assistance, and to the farmers and consumers that participated in evaluating the materials.

Conflicts of Interest: The authors declare no conflict of interest.

\section{References}

1. Ceccarelli, S. Efficiency of Plant Breeding. Crop Sci. 2015, 55, 87-97. [CrossRef]

2. Almekinders, C.J.M.; Elings, A. Collaboration of farmers and breeders: Participatory crop improvement in perspective. Euphytica 2001, 122, 425-438. [CrossRef]

3. Dawson, J.C.; Goldberger, J.R. Assessing farmer interest in participatory plant breeding: Who wants to work with scientists? Renew. Agric. Food Syst. 2008, 23, 177-187. [CrossRef]

4. Van Bueren, E.T.L.; Jones, S.S.; Tamm, L.; Murphy, K.M.; Myers, J.R.; Leifert, C.; Messmer, M.M. The need to breed crop varieties suitable for organic farming, using wheat, tomato and broccoli as examples: A review. NJAS-Wagening. J. Life Sci. 2011, 58, 193-205. [CrossRef]

5. Ceccarelli, S.; Grando, S. Decentralized-participatory plant breeding: An example of demand driven research. Euphytica 2007, 155, 349-360. [CrossRef]

6. Zeven, A.C. Landraces: A review of definitions and classifications. Euphytica 1998, 104, 127-139. [CrossRef]

7. Seufert, V.; Ramankutty, N.; Foley, J.A. Comparing the yields of organic and conventional agriculture. Nature 2012, 485, 229-232. [CrossRef]

8. De Ponti, T.; Rijk, B.; van Ittersum, M.K. The crop yield gap between organic and conventional agriculture. Agric. Syst. 2012, 108, 1-9. [CrossRef]

9. Casañas, F.; Simó, J.; Casals, J.; Prohens, J. Toward an evolved concept of landrace. Front. Plant Sci. 2017, 8, 145. [CrossRef]

10. Joshi, K.D.; Witcombe, J.R. Participatory varietal selection in rice in Nepal in favourable agricultural environments-A comparison of two methods assessed by varietal adoption. Euphytica 2002, 127, 445-458. [CrossRef]

11. Ceccarelli, S.; Grando, S. Participatory plant breeding: Who did it, who does it and where? Exp. Agric. 2019. [CrossRef]

12. Hoagland, L.; Navazio, J.; Zystro, J.; Kaplan, I.; Vargas, J.G.; Gibson, K. Key traits and promising germplasm for an organic participatory tomato breeding program in the U.S. midwest. Hortscience 2015, 50, 1301-1308. [CrossRef]

13. Campanelli, G.; Acciarri, N.; Campion, B.; Delvecchio, S.; Leteo, F.; Fusari, F.; Angelini, P.; Ceccarelli, S. Participatory tomato breeding for organic conditions in Italy. Euphytica 2015, 204, 179-197. [CrossRef]

14. Campanelli, G.; Sestili, S.; Acciarri, N.; Montemurro, F.; Palma, D.; Leteo, F.; Beretta, M. Multi-parental advances generation inter-cross population, to develop organic tomato genotypes by participatory plant breeding. Agronomy 2019, 9, 119. [CrossRef]

15. Mazzucato, A.; Ficcadenti, N.; Caioni, M.; Mosconi, P.; Piccinini, E.; Sanampudi, V.R.R.; Sestili, S.; Ferrari, V. Genetic diversity and distinctiveness in tomato (Solanum lycopersicum L.) landraces: The Italian case study of 'A pera Abruzzese'. Sci. Hortic. 2010, 125, 55-62. [CrossRef]

16. Casals, J.; Pascual, L.; Canizares, J.; Cebolla-Cornejo, J.; Casanas, F.; Nuez, F. The risks of success in quality vegetable markets: Possible genetic erosion in Marmande tomatoes (Solanum lycopersicum L.) and consumer dissatisfaction. Sci. Hortic. 2011, 130, 78-84. [CrossRef]

17. Casals, J.; Rull, A.; Bernal, M.; González, R.; del Castillo, R.R.; Simó, J. Impact of grafting on sensory profile of tomato landraces in conventional and organic management systems. Hortic. Environ. Biotechnol. 2018, 59, 597-606. [CrossRef] 
18. Chen, K.-Y.; Tanksley, S.D. High-resolution mapping and functional analysis of se2.1: A major stigma exsertion quantitative trait locus associated with the evolution from allogamy to autogamy in the genus Lycopersicon. Genetics 2004, 168, 1563-1573. [CrossRef]

19. Council of the European Union Council Regulation (EC) No 834/2007 of 28 June 2007 on Organic Production and Labelling of Organic Products and Repealing Regulation (EEC) No 2092/91; Oficial Journal of the European Union: Brussels, Belgium, 2007; p. L189/1-23.

20. Casals, J.; Rivera, A.; Sabaté, J.; Romero del Castillo, R.; Simó, J. Cherry and fresh market tomatoes: Differences in chemical, morphological, and sensory traits and their implications for consumer acceptance. Agronomy 2019, 9, 9. [CrossRef]

21. Sinesio, F.; Cammareri, M.; Moneta, E.; Navez, B.; Peparaio, M.; Causse, M.; Grandillo, S. Sensory quality of fresh French and Dutch market tomatoes: A preference mapping study with Italian consumers. J. Food Sci. 2010, 75, S55-S67. [CrossRef]

22. Figàs, M.R.; Prohens, J.; Raigón, M.D.; Pereira-Dias, L.; Casanova, C.; García-Martínez, M.D.; Rosa, E.; Soler, E.; Plazas, M.; Soler, S. Insights into the adaptation to greenhouse cultivation of the traditional Mediterranean long shelf-life tomato carrying the alc mutation: A multi-trait comparison of landraces, selections, and hybrids in open field and greenhouse. Front. Plant. Sci. 2018, 9, 1774. [CrossRef] [PubMed]

23. Eberhart, S.A.; Russell, W.A. Stability parameters for comparing varieties. Crop. Sci. 1966, 6, 36-40. [CrossRef]

24. Ortiz, R.; Izquierdo, J. Yield stability differences among tomato genotypes grown in Latin America and the Caribbean. HortScience 1994, 29, 1175-1177. [CrossRef]

25. Causse, M.; Friguet, C.; Coiret, C.; LéPicier, M.; Navez, B.; Lee, M.; Holthuysen, N.; Sinesio, F.; Moneta, E.; Grandillo, S. Consumer preferences for fresh tomato at the European scale: A common segmentation on taste and firmness. J. Food Sci. 2010, 75, S531-S541. [CrossRef] [PubMed]

26. Pacicco, L.; Bodesmo, M.; Torricelli, R.; Negri, V. A methodological approach to identify agro-biodiversity hotspots for priority in situ conservation of plant genetic resources. PLoS ONE 2018, 13, e0197709. [CrossRef] [PubMed]

27. Pico, B.; Herraiz, J.; Ruiz, J.J.; Nuez, F. Widening the genetic basis of virus resistance in tomato. Sci. Hortic. 2002, 94, 73-89. [CrossRef]

28. Montesano, V.; Negro, D.; Sarli, G.; Logozzo, G.; Spagnoletti Zeuli, P. Landraces in inland areas of the Basilicata region, Italy: Monitoring and perspectives for on farm conservation. Genet. Resour. Crop Evol. 2012, 59, 701-716. [CrossRef]

29. Casals, J.; Casañas, F.; Simó, J. Is it still necessary to continue to collect crop genetic resources in the Mediterranean area? A case study in Catalonia. Econ. Bot. 2017, 71, 330-341. [CrossRef]

30. Van de Wouw, M.; Kik, C.; van Hintum, T.; van Treuren, R.; Visser, B. Genetic erosion in crops: Concept, research results and challenges. Plant Genet. Resour. 2010, 8, 1-15. [CrossRef]

31. Maeder, P.; Fliessbach, A.; Dubois, D.; Gunst, L.; Fried, P.; Niggli, U. Soil fertility and biodiversity in organic farming. Science 2002, 296, 1694-1697. [CrossRef]

32. Desclaux, D.; Nolot, J.M.; Chiffoleau, Y.; Gozé, E.; Leclerc, C. Changes in the concept of genotype $\times$ environment interactions to fit agriculture diversification and decentralized participatory plant breeding: Pluridisciplinary point of view. Euphytica 2008, 163, 533. [CrossRef]

33. Georgelis, N.; Scott, J.W.; Baldwin, E.A. Relationship of tomato fruit sugar concentration with physical and chemical traits and linkage of RAPD markers. J. Am. Soc. Hortic. Sci. 2004, 129, 839-845. [CrossRef]

34. Ho, L.C. The mechanism of assimilate partitioning and carbohydrate compartmentation in fruit in relation Ito the quality and yield of tomato. J. Exp. Bot. 1996, 47, 1239-1243. [CrossRef] [PubMed]

35. Panthee, D.; Labate, J.; McGrath, M.; Breksa III, A.; Robertson, L. Genotype and environmental interaction for fruit quality traits in vintage tomato varieties. Euphytica 2013, 193, 169-182. [CrossRef]

36. Panthee, D.R.; Cao, C.; Debenport, S.J.; Rodríguez, G.R.; Labate, J.A.; Robertson, L.D.; Breksa, A.P.; van der Knaap, E.; McSpadden Gardener, B.B. Magnitude of genotype $\times$ environment interactions affecting tomato fruit quality. HortScience 2012, 47, 721-726. [CrossRef]

37. Prudent, M.; Causse, M.; Genard, M.; Tripodi, P.; Grandillo, S.; Bertin, N. Genetic and physiological analysis of tomato fruit weight and composition: Influence of carbon availability on QTL detection. J. Exp. Bot. 2009, 60, 923-937. [CrossRef]

38. Sperling, L.; Loevinsohn, M.E.; Ntabomvura, B. Rethinking the farmer's role in plant breeding: Local bean experts and on-station selection in Rwanda. Exp. Agric. 1993, 29, 509-519. [CrossRef] 
39. Annicchiarico, P.; Russi, L.; Romani, M.; Pecetti, L.; Nazzicari, N. Farmer-participatory vs. conventional market-oriented breeding of inbred crops using phenotypic and genome-enabled approaches: A pea case study. Field Crops Res. 2019, 232, 30-39. [CrossRef]

40. Casals, J.; Rivera, A.; Figàs, M.R.; Casanova, C.; Camí, B.; Soler, S.; Simó, J. A comparison of landraces vs. modern varieties of lettuce in organic farming during the winter in the Mediterranean area: An approach considering the viewpoints of breeders, consumers, and farmers. Front. Plant Sci. 2018, 9, 1491.

41. Folta, K.M.; Klee, H.J. Sensory sacrifices when we mass-produce mass produce. Hortic. Res. 2016, 3, 16032. [CrossRef]

42. Tieman, D.; Zhu, G.; Resende, M.F.R.; Lin, T.; Nguyen, C.; Bies, D.; Rambla, J.L.; Beltran, K.S.O.; Taylor, M.; Zhang, B.; et al. A chemical genetic roadmap to improved tomato flavor. Science 2017, 355, 391-394. [CrossRef] [PubMed]

43. Tieman, D.; Bliss, P.; McIntyre, L.M.; Blandon-Ubeda, A.; Bies, D.; Odabasi, A.Z.; Rodríguez, G.R.; van der Knaap, E.; Taylor, M.G.; Goulet, C.; et al. The chemical interactions underlying tomato flavor preferences. Curr. Biol. 2017, 22, 1035-1039. [CrossRef] [PubMed]

44. Lewinsohn, E.; Sitrit, Y.; Bar, E.; Azulay, Y.; Meir, A.; Zamir, D.; Tadmor, Y. Carotenoid pigmentation affects the volatile composition of tomato and watermelon fruits, as revealed by comparative genetic analyses. J. Agric. Food Chem. 2005, 53, 3142-3148. [CrossRef] [PubMed]

(C) 2019 by the authors. Licensee MDPI, Basel, Switzerland. This article is an open access article distributed under the terms and conditions of the Creative Commons Attribution (CC BY) license (http://creativecommons.org/licenses/by/4.0/). 